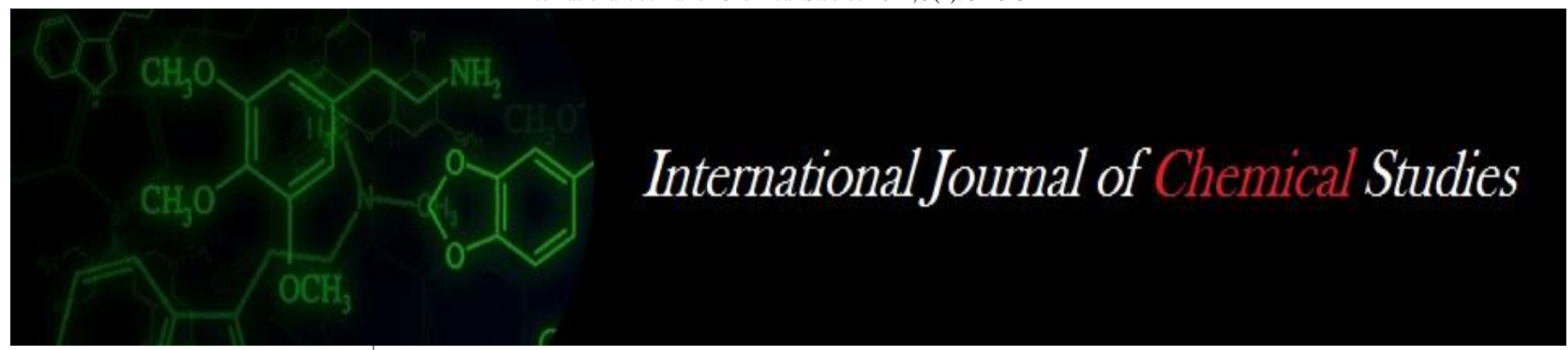

P-ISSN: 2349-8528

E-ISSN: 2321-4902

www.chemijournal.com

IJCS 2021; 9(1): 3419-3422

(C) 2021 IJCS

Received: 12-11-2020

Accepted: 23-12-2020

\section{Saumitra Devavrata}

Department of Horticulture,

Naini Agricultural Institute,

Sam Higginbottom University of

Agriculture, Technology and

Sciences, Prayagraj, Uttar

Pradesh, India

\section{Vijay Bahadur}

Department of Horticulture,

Naini Agricultural Institute,

Sam Higginbottom University of

Agriculture, Technology and

Sciences, Prayagraj, Uttar

Pradesh, India
Corresponding Author: Saumitra Devavrata

Department of Horticulture, Naini Agricultural Institute,

Sam Higginbottom University of

Agriculture, Technology and

Sciences, Prayagraj, Uttar

Pradesh, India

\section{Effect of different growing media on vegetative growth and flowering of petunia (Petunia hybrida L.) in vertical garden}

\author{
Saumitra Devavrata and Vijay Bahadur
}

DOI: $\underline{\text { https://doi.org/10.22271/chemi.2021.v9.i1av.11764 }}$

\begin{abstract}
The present experiment was carried out in winter season at 2020 in the Research Field, Department of Horticulture, SHUATS, Prayagraj. The experiment was conducted in Randomized Block Design (RBD), with eight treatments, replicated thrice with growing media (Cocopeat + Perlite + Vermicompost) on Petunia. From the present experimental findings it is found that treatment T7 (Cocopeat, perlite, vermicompost, 2:2:1) was found best in terms of growth parameters followed by T3 (Cocopeat, perlite, vermicompost (1:2:1) and T4 (Cocopeat, perlite, vermicompost (1:2:2).In earliness parameters T6 (Cocopeat, perlite, vermicompost $(2: 1: 2)$ was best followed by T7(Cocopeat, perlite, vermicompost $(2: 2: 1)$ found superior. In terms of flowering and yield parameters treatment T5 (Cocopeat, perlite, vermicompost (2:1:1) was superior followed by T3 Cocopeat, perlite, vermicompost (1:2:1) and T7 (Cocopeat, perlite, vermicompost (2:2:1). Minimum vegetative growth and no flowering and fruiting were recorded in control.
\end{abstract}

Keywords: Petunia, growing media, growth, flowering and vertical garden

\section{Introduction}

Petunia (Petunia hybrida L.) is an annual or perennial plant belonging to the family solanaceae. The common kinds are weedy in habit, but their great profusion of bloom under all conditions makes them useful and popular. It is a decorative plant, grown for its beautiful flowers in beddings, borders, and pots, hanging baskets, window boxes and containers. In warm climates petunias are perennial but are used as annuals in temperate zones.

Petunia is considered to be first cultivated bedding plant and has remained as a commercially important ornamental crop since the early days of horticulture and is one of the favourite genera for developing new varieties. Apart from its significance as an ornamental crop, petunia has proved to be one of the most excellent model crops for studies of gene regulation and genome structure, since the system combines innumerable and excellent technical features with a broad range of research possibilities.

Vertical garden is the solution to implement beautiful plant in any location where there are no horizontal places left for plants. So far, there are roughly 1000+ vertical gardens around the world. The largest Vertical Garden is in Paris. It has surface of $300 \mathrm{~m}$, is $30 \mathrm{~m} \mathrm{high,} \mathrm{and} \mathrm{can}$ be implemented in any environment (light, wind, temperature, air humidity, either indoor or outdoor).

\section{Materials and Methods}

The present Experiment was conducted in Randomized Block Design (RBD), with Petunia variety Red Star, total 8 numbers of treatments, replicated thrice, in the Research field, Department of Horticulture, Sam Higginbottom University of Agriculture, Technology and Sciences, Prayagraj during December, 2019 to April, 2020.

\section{Results and Discussion}

The present investigation entitled "Effect of different growing media on vegetative growth and flowering of Petunia (Petunia hybrida L.) In vertical garden" was carried out during December, 2019 to April, 2020 in Research Field, Department of Horticulture, Naini 
Agricultural Institute, Sam Higginbottom University of Agriculture, Technology and Sciences, Prayagraj (U.P.) India. The results of the present investigation, regarding the effect of different growing media on growth, flowering and flower yield parameters of Petunia, have been discussed and interpreted in the light of previous research work done in India and abroad. The results of the experiment are summarized below.

\section{A. Growth parameters}

The data on growth parameters are given in table 1. It is clear from the table that all the treatment differed significantly for all growth parameters. Significantly maximum Plant height $17.74 \mathrm{~cm}$, was noticed in the treatment $\mathrm{T}_{6}$ (Cocopeat, perlite, vermicompost, 2:1:2) followed by $\mathrm{T}_{4}$ (Cocopeat, perlite, vermicompost, $1: 2: 2)$ with $(16.02 \mathrm{~cm})$ and minimum $(12.42$ $\mathrm{cm}$ ) recorded in $\mathrm{T}_{0}$ (Garden Soil (Control). Similarly for Number of leaves/plant maximum (101.54 leaves/plant) was recorded in treatment $\mathrm{T}_{6}$ (Cocopeat, perlite, vermicompost, 2:1:2), followed by $\mathrm{T}_{4}$ (Cocopeat, perlite, vermicompost, $1: 2: 2)$ with (93.40 leaves/plant) and minimum (61.98 leaves) recorded in $\mathrm{T}_{0}$ (Garden Soil (Control). The increased plant height in treatment $T_{6}$ is due to the growing media of Cocopeat, perlite and Vermicompost, throughout the experimental period might be due to the retention of optimum moisture, good aeration in the root zone and the ability of these growing media to supply ample quantities of nutrients to plants in order to sustain the development and growth of roots and shoots. This findings correlates with the findings of Wazir et al. (2009) ${ }^{[11]}$ in Alstroemeria and Gowda and Ramakrishna (2009) ${ }^{[4]}$ in Anthurium. Sarkar (2018) ${ }^{[8]}$ in chrysanthemum. Dabral et al. (2019) ${ }^{[2]}$ in calla lily. The increase in number of leaves could be attributed to the fact that the organic component i.e. cocopeat and Vermicompost might have improved the physical structure of the substrate by reducing weight which in turn increases its water holding properties. It also has high cation exchange capacity (CEC) and thus can store nutrients until needed by the plant. All these factors might have contributed to cell multiplication, cell enlargement and differentiation which could have resulted in better photosynthesis and ultimately the plant exhibited more number of leaves per plant. Similar findings were reported by Gowda and Ramakrishna (2009) ${ }^{[4]}$ in Anthurium and Gupta et al. (2004) ${ }^{[5]}$ in Gerbera cv. Paganini and they reported that cocopeat alone enhanced the plant growth parameters viz. plant spread and number of leaves per plant. Sarkar (2018) ${ }^{[8]}$ in chrysanthemum. Dabral et al. (2019) ${ }^{[2]}$ in calla lily.

In terms of Plant spread maximum significant plant spread $\left(16.42 \mathrm{~cm}\right.$ ), was noticed in treatment $\mathrm{T}_{6}$ (Cocopeat, perlite, vermicompost, 2:1:2), followed by $\mathrm{T}_{4}$ (Cocopeat, perlite, vermicompost, 1:2:2) with $(15.66 \mathrm{~cm})$ and minimum $(10.42$ $\mathrm{cm}$ ) recorded in $\mathrm{T}_{0}$ (Garden Soil (Control). This increase is might be due to the moisture availability and nutritional status of cocopeat, perlite and vermicompost media. The higher water holding capacity, aeration and available organic matter of the cocopeat and vermicompost might be responsible for increased vegetative growth. This is in line with the findings of Dewayne et al. (2003) ${ }^{\text {[3] }}$ as they reported that physical properties like aeration and water holding capacity are probably the most important factors in plant development. The above results are also correlated with the findings of Awang et al. (2010) ${ }^{[1]}$ in Celosia cristata. Sarkar (2018) ${ }^{[8]}$ in chrysanthemum. Dabral et al. (2019) ${ }^{[2]}$ in calla lily.

In earliness parameter i.e. Days to flower bud appearance significantly, minimum days for flower bud appearance 42.41 days, was recorded in treatment $\mathrm{T}_{6}$ (Cocopeat, perlite, vermicompost, 1:2:2), followed by followed by $\mathrm{T}_{4}$ (Cocopeat, perlite, vermicompost, 1:2:2) with (46.90 days) and maximum (60.73 days) recorded in $\mathrm{T}_{0}$ (Garden Soil (Control). Similarly in days to flower opening minimum 50.44 days, was noticed in treatment $\mathrm{T}_{6}$ (Cocopeat, perlite, vermicompost, 1:2:2) followed by $\mathrm{T}_{4}$ (Cocopeat, perlite, vermicompost, 1:2:2) with (55.68 days) and maximum (75.43 days) recorded in $\mathrm{T}_{0}$ (Garden Soil (Control). Early flowering in treatment $T_{6}$ is might be due to the incorporation of the amendments such as cocopeat, vermicompost and perlite showed the increasing trend in available $\mathrm{N}, \mathrm{P}$ and $\mathrm{K}$ content in the growing media which caused an increase in the synthesis of cytokinin in the root tissue and its simultaneous transport to axillary buds would have resulted in better sink for mobilization of photo assimilates at a rapid rate. Sindhu et al. $2010^{[9]}$. This might have helped in the early transformation from vegetative to reproductive phase and thus early bud initiation and bud opening of flowers. Similar results have been reported by Kumar et al. $2011^{[6]}$ and Singh et al. (2013) ${ }^{[10]}$ in Gladiolus. Sarkar (2018) ${ }^{[8]}$ in chrysanthemum. Dabral et al. (2019) ${ }^{[2]}$ in calla lily.

\section{B. Yield parameters}

The data on growth parameters are given in table 1. It is clear from the table that all the treatment differed significantly for in yield parameter. Significantly maximum flower diameter $6.23 \mathrm{~cm}$, was noticed in treatment $\mathrm{T}_{6}$ (Cocopeat, perlite, vermicompost, 1:2:2), followed by $\mathrm{T}_{4}$ (Cocopeat, perlite, vermicompost, $1: 2: 2)$ with $(5.47 \mathrm{~cm})$ and minimum $(4.05 \mathrm{~cm})$ recorded in $\mathrm{T}_{0}$ (Garden Soil (Control). Maximum flower diameter in treatment $\mathrm{T}_{6}$ during the experimental period might be due to the different growing media percentage in the pots which in turn facilitates availability of essential nutrients resulting in increase in cell division, cell elongation and cell size. The increased flower length and flower diameter may be related to the optimum growing condition of the medium. Maximum length and diameter might be due to the fact that root aeration was more due to the use of perlite and thus compactness of growing media has been avoided and drainage was facilitated by media which affected the uptake of nutrients by the plants thereby producing superior quality flowers. This finding correlates with the finding of Syros et al. (2001) in Gerbera. Sarkar (2018) ${ }^{[8]}$ in chrysanthemum. Dabral et al. (2019) ${ }^{[2]}$ in calla lily.

In terms of number of flowers/plant, maximum significant number of flowers per plant 21.11 flowers, was noticed in treatment $\mathrm{T}_{6}$ (Cocopeat, perlite, vermicompost, 1:2:2) followed by $\mathrm{T}_{4}$ (Cocopeat, perlite, vermicompost, 1:2:2) with (16.43 flowers) and minimum (8.72 flowers) recorded in $\mathrm{T}_{0}$ (Garden Soil (Control). This increase in number of flowers per plant can be attributed to the use of cocopeat with perlite and vermicompost as a growing media which possibly have increased the nutrient status and physical properties and also the vegetative growth was recorded maximum in this media, so it would have influenced positively on flower production. The physical and chemical characteristics of the growing medium might have exerted substantial effect on growth of Petunia plants. Cocopeat as a growing media might have provided better growing condition and vermicompost along with cocopeat must have increased the nutritional status of the growing media thus ultimately resulting in vigorous vegetative growth and increased carbohydrate reserve with the proper uptake of all available nutrients and thus increase in the number of flowers per plant and per pot. These findings 
are supported with the findings of Gupta et al. $2004^{\text {[5] in }}$ Gerbera as they reported that media containing cocopeat exhibited maximum number of flowers per plant. Ntoulas et al. (2011) ${ }^{[7]}$ in Petunia. Sarkar (2018) ${ }^{[8]}$ in chrysanthemum. Dabral et al. (2019) ${ }^{[2]}$ in calla lily.

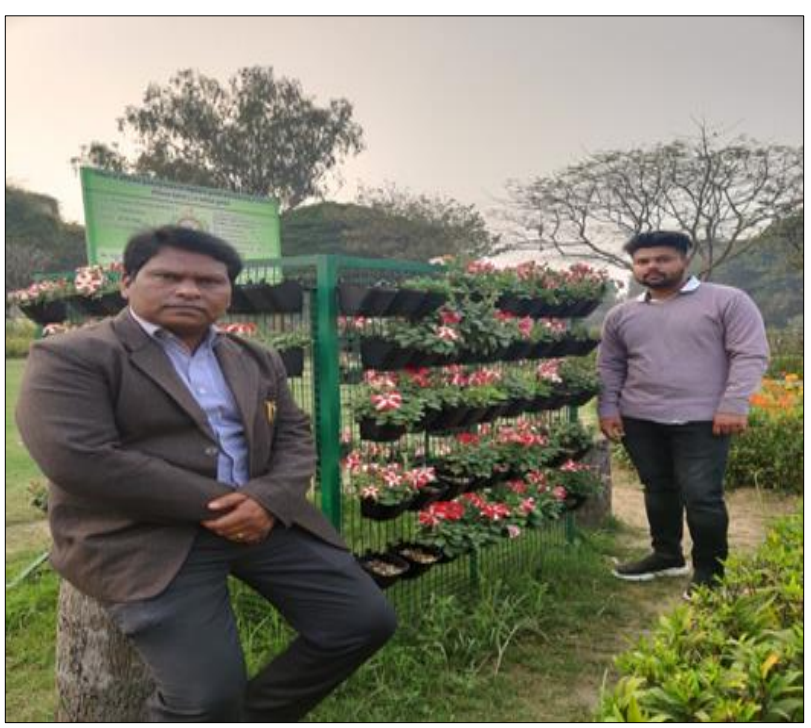

Fig 1: Field visit with my Advisor Dr. Vijay Bahadur

Table 1: Effect of different growing media on growth, earliness and yield parameters of Petunia in vertical Garden

\begin{tabular}{|c|c|c|c|c|c|c|c|c|}
\hline $\begin{array}{c}\text { Treatment } \\
\text { Symbol }\end{array}$ & Treatment Combination & $\begin{array}{l}\text { Plant Height } \\
\text { (cm) 90 DAS }\end{array}$ & $\begin{array}{l}\text { Number of } \\
\text { leaves/plant } \\
90 \text { DAS }\end{array}$ & $\begin{array}{l}\text { Plant spread } \\
(\mathrm{cm}) 90 \text { DAS }\end{array}$ & \begin{tabular}{|c|} 
Days to \\
flower bud \\
emergence
\end{tabular} & $\begin{array}{c}\text { Days to } \\
\text { flower } \\
\text { opening }\end{array}$ & \begin{tabular}{|c|}
$\begin{array}{c}\text { Flower } \\
\text { diameter } \\
(\mathrm{cm})\end{array}$ \\
\end{tabular} & $\begin{array}{c}\text { Number of } \\
\text { flowers/plant }\end{array}$ \\
\hline $\mathrm{T}_{1}$ & Cocopeat, Perlite, Vermicompost (1:1:1) & 12.30 & 69.51 & 12.36 & 55.76 & 68.23 & 4.30 & 13.05 \\
\hline $\mathrm{T}_{2}$ & Cocopeat, Perlite, Vermicompost $(1: 1: 2)$ & 13.38 & 74.09 & 13.40 & 53.82 & 63.98 & 5.22 & 14.10 \\
\hline $\mathrm{T}_{3}$ & Cocopeat, Perlite, Vermicompost $(1: 2: 1)$ & 14.30 & 65.59 & 12.71 & 55.30 & 67.84 & 4.26 & 11.78 \\
\hline $\mathrm{T}_{4}$ & Cocopeat, Perlite, Vermicompost (1:2:2) & 16.02 & 93.40 & 15.66 & 46.90 & 55.68 & 5.47 & 16.43 \\
\hline $\mathrm{T}_{5}$ & Cocopeat, Perlite, Vermicompost (2:1:1) & 13.49 & 87.13 & 13.91 & 52.18 & 60.37 & 5.07 & 12.75 \\
\hline $\mathrm{T}_{6}$ & Cocopeat, Perlite, Vermicompost (2:1:2) & 17.74 & 101.54 & 16.42 & 42.41 & 50.44 & 6.23 & 21.11 \\
\hline $\mathrm{T}_{7}$ & Cocopeat, Perlite, Vermicompost (2:2:1) & 13.37 & 83.98 & 12.25 & 57.28 & 66.55 & 4.54 & 11.38 \\
\hline $\mathrm{T}_{0}$ & Garden Soil (Control) & 12.42 & 61.98 & 10.42 & 60.73 & 75.43 & 4.05 & 8.72 \\
\hline \multicolumn{2}{|r|}{ F-Test } & $\mathrm{S}$ & $\mathrm{S}$ & $\mathrm{S}$ & $\mathrm{S}$ & $\mathrm{S}$ & $\mathrm{S}$ & $\mathrm{S}$ \\
\hline \multicolumn{2}{|r|}{$\mathrm{SE}(\mathrm{d})$} & 0.140 & 0.857 & 0.332 & 0.591 & 0.571 & 0.119 & 0.287 \\
\hline \multicolumn{2}{|r|}{ C.V. } & 1.215 & 1.317 & 3.037 & 1.365 & 1.100 & 2.985 & 2.574 \\
\hline \multicolumn{2}{|r|}{ C.D. at $5 \%$} & 0.303 & 1.856 & 0.719 & 1.280 & 1.236 & 0.258 & 0.622 \\
\hline
\end{tabular}

\section{Conclusion}

From the present experimental findings it is concluded that treatment $\mathrm{T}_{6}$ (Cocopeat, perlite, vermicompost, 2:1:2) was found best in terms of vegetative growth and flowering of Petunia in vertical garden.

\section{References}

1. Awang Y, Shaharom A, Mohamad SRB, Selamat A. Growth dynamics of Celosia cristata grown in cocopeat, Burnt Rice Hull and Kenaf Core Fiber mixtures. American Journal of Agricultural and Biological Sciences 2010;5(1):70-76.

2. Dabral M, Punetha P, Bohra M. Assesment of different substrates for pot culture in calla lily (Zantedeschia sprengeri). International Journal of Chemical Studies 2019;7(3):269-274.

3. Dewayne LI, Richard WH, Thomas HY. Growth media for container grown ornamental plants. The Environmental Horticulture Department, Florida cooperative extension service, Institute of Food and Agriculture Sciences, University of Florida 2003.

4. Gowda JVN, Ramakrishna BM. Evaluation and effect of growing media, biofertilizers and growth regulator on growth and flowering in Anthurium. In: Book of
Abstract. National Conference on Floriculture for Livelihood and Profitability on 16-19 March, 2009 at IARI, New Delhi 2009, 1-5.

5. Gupta YC, Le QD, Dhiman SR, Jain R. Standardization of growing media under protected environment for gerbera in mid hill of Himachal Pradesh. Journal of Ornamental Horticulture 2004;7(1):99-102.

6. Kumar J, Kumar R, Pal K. Variability and character association in gladiolus (Gladiolus grandiflorus L.). Agricultural Science Digest 2011;31(4):30.

7. Ntoulas N, Nektarios PA, Gogoula G. Evaluation of olive mill waste compost as a soil amendment for Cynodon dactylon turf establishment, growth, and anchorage. HortScience 2011;46:937-945.

8. Sarkar AN. Selection of Plants for Vertical Gardening and Green Roof Farming. International Research Journal of Plant and Crop Sciences 2018;4(3):132-153.

9. Sindhu SS, Gholap DB, Singh MC, Dhiman MR. Effect of medium amendments on growth and flowering in gerbera. Indian Journal of Horticulture 2010;67:391-394.

10. Singh R, Kumar M, Raj S, Kumar S. Effect of integrated nutrient management INM on growth and flowering in Gladiolus (Gladiolus grandiflorus L.) cv. White Prosperity. Annals of Horticulture 2013;6(2):242-251. 
11. Syros T, Economou A, Exarchou E, Schmidt U. Flower and growth evaluation of Gerbera cultivated on perlite in an open hydroponic system. Acta Horticulturae, 2001;548:625-630

12. Wazir J, Sharma YD, Dhiman SR. Performance of potted Alstromeria (Alstroemeria hybrid L.) in different growing media under wet temperate conditions. Journal of Ornamental Horticulture 2009;12:167-174. 